\title{
OPEN Author Correction: Widespread distribution of supraglacial lakes around the margin of the East Antarctic Ice Sheet
}

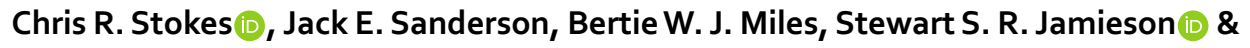 \\ Amber A. Leeson
}

Correction to: Scientific Reports https://doi.org/10.1038/s41598-019-50343-5, published online 25 September 2019

This Article contains a typographical error in the Methods section under subheading 'Image processing and automated supraglacial lake identification and mapping' where,

"This equation (Eq. 1) was therefore used to classify each image into 'water' or 'no-water' regions using a threshold value that was interactively selected:

$$
N D W I=\frac{\text { Green }-N I R}{\text { Green }+ \text { NIR }}
$$

where 'Green' is Band 3 of the Sentinel imagery and Band 3 of the Landsat 8 imagery, and 'NIR' is Band 4 of the Sentinel imagery and Band 5 of the Landsat imagery"

should read:

"This equation (Eq. 1) was therefore used to classify each image into 'water' or 'no-water' regions using a threshold value that was interactively selected:

$$
N D W I=\frac{\text { Green }-N I R}{\text { Green }+ \text { NIR }}
$$

where 'Green' is Band 3 of the Sentinel imagery and Band 3 of the Landsat 8 imagery, and 'NIR' is Band 8 of the Sentinel imagery and Band 5 of the Landsat imagery"

(c) (i) Open Access This article is licensed under a Creative Commons Attribution 4.0 International License, which permits use, sharing, adaptation, distribution and reproduction in any medium or format, as long as you give appropriate credit to the original author(s) and the source, provide a link to the Creative Commons license, and indicate if changes were made. The images or other third party material in this article are included in the article's Creative Commons license, unless indicated otherwise in a credit line to the material. If material is not included in the article's Creative Commons license and your intended use is not permitted by statutory regulation or exceeds the permitted use, you will need to obtain permission directly from the copyright holder. To view a copy of this license, visit http://creativecommons.org/licenses/by/4.0/.

(c) The Author(s) 2020 